\title{
A Convenient Synthetic Route towards the Hybrid Binuclear Metallophthalocyaninato-Capped Iron and Nickel(II) Tris-pyridineoximates
}

\author{
Semyon V. Dudkin, ${ }^{a} @$ Svetlana A. Savkina, ${ }^{a}$ Alexander S. Belov, ${ }^{a}$ \\ and Yan Z. Voloshina,b \\ ${ }^{a}$ Nesmeyanov Institute of Organoelement Compounds of Russian Academy of Sciences, 119991 Moscow, Russia \\ ${ }^{\mathrm{b}}$ Kurnakov Institute of General and Inorganic Chemistry of Russian Academy of Sciences, 119991 Moscow, Russia \\ ${ }^{\circledR}$ Corresponding author E-mail: sdudkin@ineos.ac.ru
}

\begin{abstract}
Earlier, the hybrid binuclear metallophthalocyaninate-capped iron and nickel(II) tris-pyridineoximates have been prepared using a two-step synthetic procedure via transmetalation reaction of their labile triethylantimony-capped precursors. We elaborated new efficient synthetic pathway to the preparation of the titled complexes. This synthetic approach is based on a one-pot template condensation of 2-acetylpyridinoxime with zirconium and hafnium(IV) phthalocyaninate on the corresponding metal ion(II) as a matrix, thus giving the target compounds in high yields (up to $83 \%$ ).
\end{abstract}

Keywords: Macrocyclic compounds, polynuclear complexes, template reaction, iron complexes, nickel complexes, phthalocyanines, zirconium complexes, hafnium complexes.

\section{УАобный метод получения гибридных биядерных металлофталоцианинатосодержащих трис-пиридиноксиматов железа и никеля(II)}

\author{
С. В. Аудкин, ${ }^{a} @$ C. А. Савкина, ${ }^{a}$ А. С. Белов, ${ }^{a}$ Я. З. Волошинн \\ ${ }^{\mathrm{a}}$ Институт элементоорганических соединений им. А.Н. Несмеянова РАН, 119991 Москва, Россия \\ ${ }^{\mathrm{b}}$ Институт общей и неорганической химии им. Н.С. Курнакова РАН, 119991 Москва, Россия \\ @E-mail: sdudkin@ineos.ac.ru
}

\begin{abstract}
Ранее нами было описано получение гибридных биядерных металлофталоцианинато-сиитых триспиридиноксиматов железа и никеля(II) переметаллированием их сурьма-содержащчих предшественников. Мы разработали новый эффективный синтетический путь для получения таких комплексов. Этот путь использует одностадийную темплатную конденсацию 2-ацетилпиридиноксима с фталоцианинатами ичиркония и гафния(IV) на матрице - ионе соответствующего металла(II), и позволяет получать искомые соединения с высокими выходами (до $83 \%$ ).
\end{abstract}

Ключевые слова: Макроциклические соединения, полиядерные комплексы, темплатная реакция, комплексы железа, комплексы никеля, фталоцианины, комплексы циркония, комплексы гафния.

\section{Introduction}

Cage metal complexes and their pseudomacrobicyclic analogs with an encapsulated metal ion (clathroche- lates) ${ }^{[1,2]}$ are forms an individual class of the coordination compounds possessing unusual or, even, unique chemical reactivity, physical and physicochemical (including redox) properties. 
Tetrapyrrole- (phthalocyaninate- or porphyrinate-) capped cage and pseudocage metal complexes belong to a subclass of hybrid clathrochelate-based compounds and several types of them with various (pseudo)encapsulated metal ions and different capping fragments have been synthesized to date. ${ }^{[3-7]}$ Recently, ${ }^{[6]}$ we reported a two-step synthetic approach (Scheme 1) that allowed to obtain the binuclear metallophthalocyaninate-capped metal(II) tris-pyridineoximates using a transmetallation of the initially obtained antimony-capped iron and nickel(II) tris-pyridineoximates with zirconium and hafnium(IV) phthalocyaninates as Lewis acids.

The transmetallation (a capping group exchange) reaction is a most common synthetic approach for the preparation of the hybrid cage metal complexes with tetrapyrrolic macroheterocyclic capping groups. ${ }^{[3-7]}$ However, the use of an extremely toxic triethylantimony(V) dibromide as a capping agent in this two-step procedure, thus allowing to isolate of the trialkylantimony-capped (pseudo-)clathrochelate complexes with labile capping groups, is its main disadvantage. In the present paper, we report an efficient antimony-free synthesis of the hybrid binuclear metallophthalocyaninate-capped iron and nickel(II) tris-pyridineoximates, allowing to obtain them in the moderate or, even high yields using their one-pot template self-assembly.

\section{Experimental}

The materials used and the details of the spectral experiments are described previously. ${ }^{[6]}$

General procedure for the preparation of metal(IV) phthalocyaninate-capped iron and nickel(II) complexes. 2-Acetylpyridineoxime was dissolved in ethanol-chlorobenzene 2:3 (v/v) mixture $(5 \mathrm{~mL})$ and $\mathrm{NaClO}_{4} \cdot \mathrm{H}_{2} \mathrm{O}, \mathrm{NaHCO}_{3}$, the corresponding metallophthalocyaninate $\left\{\mathrm{Zr}\left(\mathrm{Cl}_{2}\right) \mathrm{Pc}\right.$ or $\left.\mathrm{Hf}\left(\mathrm{Cl}_{2}\right) \mathrm{Pc}\right\}$ and the corresponding metal(II) salt $\left\{\mathrm{FeCl}_{2} \cdot 4 \mathrm{H}_{2} \mathrm{O}\right.$ or $\left.\mathrm{Ni}\left(\mathrm{ClO}_{4}\right)_{2} \cdot 6 \mathrm{H}_{2} \mathrm{O}\right\}$ were added under argon. The reaction mixture was refluxed with stirring for 0.5 $\mathrm{h}$. Then the reaction mixture was cooled to room temperature and the precipitate formed was filtered off, washed with ethanol $(10 \mathrm{~mL}$, in two portions), diethyl ether $(5 \mathrm{~mL})$ and dried in vacuo for $1 \mathrm{~h}$. The solid product was extracted with dichloromethane (15 $\mathrm{mL}$, in three portions), the extract was rotary evaporated to a small volume (approximately $5 \mathrm{~mL}$ ) and, then, it was purified by column chromatography on $\mathrm{Al}_{2} \mathrm{O}_{3}$ (eluent: chloroform - methanol 5: 1 (v/v) mixture. The major elute was collected, filtered and evaporated to dryness. The solid residue was washed with hexane and dried in vacuo.

$\left[\mathrm{Fe}(\mathrm{AcPyOx})_{3}(\mathrm{HfPc})\right](\mathrm{ClO})$. 2-Acetylpyridineoxime $(0.057 \mathrm{~g}$, $0.419 \mathrm{mmol}), \mathrm{NaClO}_{4} \cdot \mathrm{H}_{2} \mathrm{O}(0.084 \mathrm{~g}, 0.599 \mathrm{mmol}), \mathrm{NaHCO}$

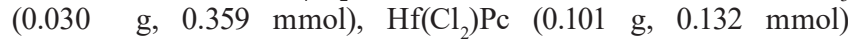
and $\mathrm{FeCl}_{2} \cdot 4 \mathrm{H}_{2} \mathrm{O}(0.024 \mathrm{~g}, 0.120 \mathrm{mmol})$ were used. The product was separated and purified as described above. Yield: $0.108 \mathrm{~g}$ (72\%).

$\left[\mathrm{Fe}(\mathrm{AcPyOx})_{3}(\mathrm{ZrPc})\right]\left(\mathrm{ClO}_{4}\right) . \quad$ 2-Acetylpyridineoxime $(0.017 \mathrm{~g}, 0.123 \mathrm{mmol}), \mathrm{NaClO}_{4} \cdot \mathrm{H}_{2} \mathrm{O}(0.015 \mathrm{~g}, 0.105 \mathrm{mmol})$, $\mathrm{NaHCO}_{3}(0.009 \mathrm{~g}, 0.105 \mathrm{mmol}), \mathrm{Zr}\left(\mathrm{Cl}_{2}\right) \mathrm{Pc}(0.026 \mathrm{~g}, 0.39 \mathrm{mmol})$ and $\mathrm{FeCl}_{2} \cdot 4 \mathrm{H}_{2} \mathrm{O}(0.007 \mathrm{~g}, 0.35 \mathrm{mmol})$ were used. The product was separated and purified as described above. Yield: $0.033 \mathrm{~g}$ (83\%).

$\left[\mathrm{Ni}(\mathrm{AcPyOx})_{3}(\mathrm{HfPc})\right]\left(\mathrm{ClO}_{4}\right) . \quad$ 2-Acetylpyridineoxime $(0.057 \mathrm{~g}, 0.419 \mathrm{mmol}), \mathrm{NaClO}_{4} \cdot \mathrm{H}_{2} \mathrm{O}(0.034 \mathrm{~g}, 0.239 \mathrm{mmol})$, $\mathrm{NaHCO}_{3}(0.020$ g, $0.239 \mathrm{mmol}), \mathrm{Hf}\left(\mathrm{Cl}_{2}\right) \mathrm{Pc}(0.101 \mathrm{~g}, 0.132 \mathrm{mmol})$ and $\mathrm{Ni}\left(\mathrm{ClO}_{4}\right) \cdot 6 \mathrm{H}_{2} \mathrm{O}(0.044 \mathrm{~g}, 0.120 \mathrm{mmol})$ were used. The product was separated and purified as described above. Yield: $0.098 \mathrm{~g}$ (65\%).

[Ni( $\left.\mathrm{AcPyOx})_{3}(\mathrm{ZrPc})\right]\left(\mathrm{ClO} \mathrm{O}_{4}\right)$. 2-Acetylpyridineoxime $(0.016 \mathrm{~g}$, $0.119 \mathrm{mmol}), \mathrm{NaClO}_{4} \cdot \mathrm{H}_{2} \mathrm{O}(0.014 \mathrm{~g}, 0.102 \mathrm{mmol}), \mathrm{NaHCO}_{3}(0.009 \mathrm{~g}$, $0.102 \mathrm{mmol}), \mathrm{Zr}\left(\mathrm{Cl}_{2}\right) \mathrm{Pc}(0.025 \mathrm{~g}, 0.37 \mathrm{mmol})$ and $\mathrm{Ni}\left(\mathrm{ClO}_{4}\right)_{2} \cdot 6 \mathrm{H}_{2} \mathrm{O}$ $(0.012 \mathrm{~g}, 0.34 \mathrm{mmol})$ were used. The product was separated and purified as described above. Yield: $0.027 \mathrm{~g}(68 \%)$.

\section{Results and Discussion}

The hybrid binuclear metallophthalocyaninate-capped complexes under study were obtained in the yields from moderate to high (Table 1) by Scheme 2 using the direct template condensation of 2-acetylpyridineoxime with an equimolar amount of the Lewis-acidic zirconium or hafnium(IV) phthalocyaninates on the corresponding metal ion(II) as a matrix.

A formation of the known ${ }^{[6]}$ metallophthalocyaninatecapped tris-pyridineoximates was confirmed by elemental analysis, 1D $\left({ }^{1} \mathrm{H}\right.$ and $\left.{ }^{13} \mathrm{C}\left\{{ }^{1} \mathrm{H}\right\}\right)$ and 2D NMR, MALDI-TOF MS data, as well as using their UV-Vis spectra (Figure 1). All the spectral data for these isolated complexes were identical to those described previously. ${ }^{[6]}$

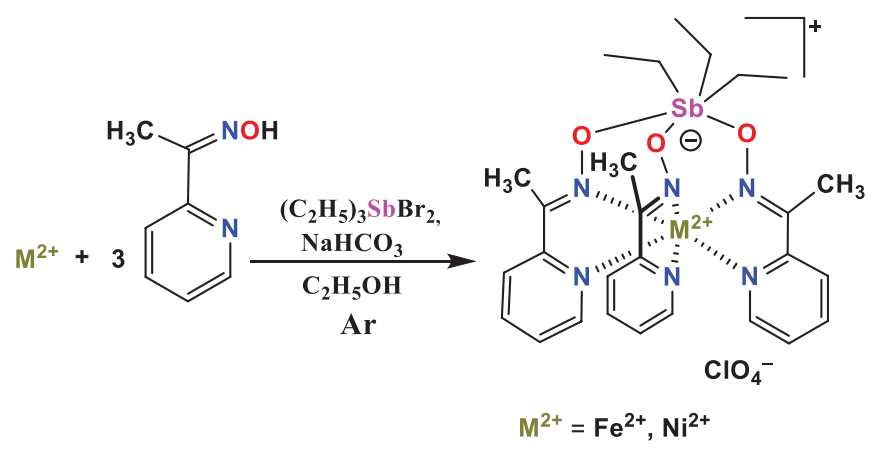

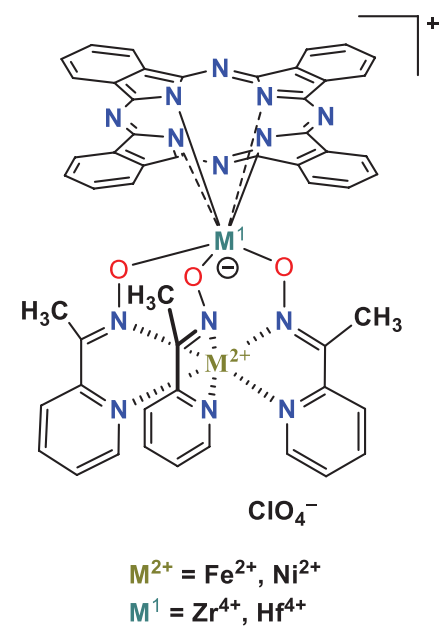

Scheme 1. 


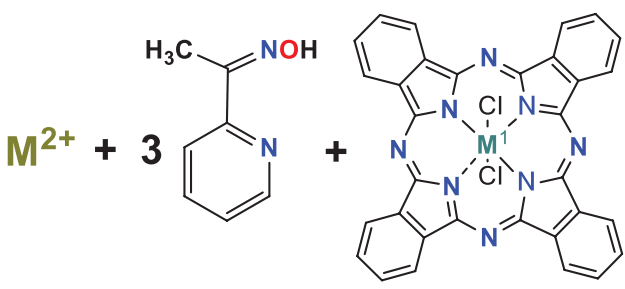

$\mathrm{M}^{2+}=\mathrm{Fe}^{2+}, \mathrm{Ni}^{2+}$

$\mathrm{M}^{1}=\mathrm{Zr}^{4+}, \mathbf{H f}^{4+}$

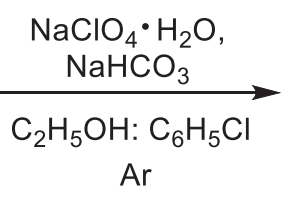

$\mathrm{Ar}$

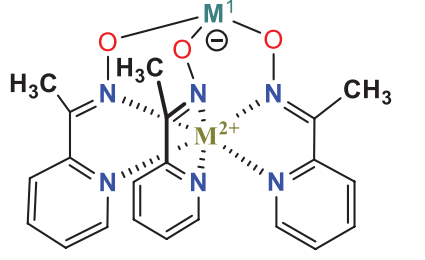

$\mathrm{ClO}_{4}^{-}$

$\left[\mathrm{Fe}(\mathrm{AcPyOx})_{3}(\mathrm{ZrPc})\right]\left(\mathrm{ClO}_{4}\right): \mathrm{M}^{2+}=\mathrm{Fe}^{2+}, \mathrm{M}^{1}=\mathrm{Zr}^{4+}$ $\left[\mathrm{Fe}(\mathrm{AcPyOx})_{3}(\mathrm{HfPc})\right]\left(\mathrm{ClO}_{4}\right): \mathrm{M}^{2+}=\mathrm{Fe}^{2+}, \mathrm{M}^{1}=\mathrm{Hf}^{4+}$ $\left[\mathrm{Ni}(\mathrm{AcPyOx})_{3}(\mathrm{ZrPc})\right]\left(\mathrm{ClO}_{4}\right): \mathrm{M}^{2+}=\mathrm{Ni}^{2+}, \mathrm{M}^{1}=\mathrm{Zr}^{4+}$ $\left[\mathrm{Ni}(\mathrm{AcPyOx})_{3}(\mathrm{HfPc})\right]\left(\mathrm{ClO}_{4}\right): \mathrm{M}^{2+}=\mathrm{Ni}^{2+}, \mathrm{M}^{1}=\mathrm{Hf}^{4+}$

Scheme 2.

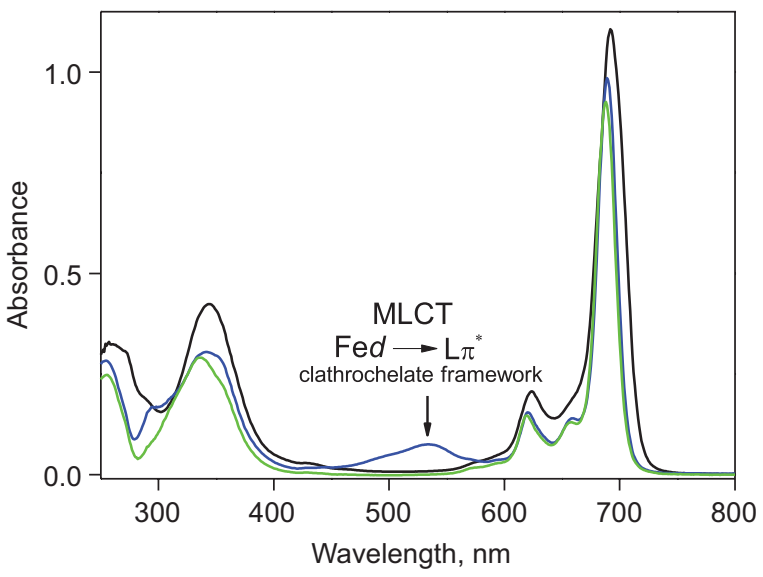

Figure 1. UV-Vis spectrum of a DMSO solution of the parent $\mathrm{Hf}\left(\mathrm{Cl}_{2}\right) \mathrm{Pc}$ (black) and that of its derivatives $\left[\mathrm{Fe}(\mathrm{AcPyOx})_{3}(\mathrm{HfPc})\right]$ $\left(\mathrm{ClO}_{4}\right)$ (blue) and $\left[\mathrm{Ni}(\mathrm{AcPyOx})_{3}(\mathrm{HfPc})\right]\left(\mathrm{ClO}_{4}\right)$ (green) in $\mathrm{CH}_{2} \mathrm{Cl}_{2}$.

\section{Conclusions}

We elaborated a new direct synthetic approach for preparation of the hybrid binuclear metallophthalocyaninate-capped iron and nickel(II) tris-pyridineoximates using the one-pot reaction giving them in the yields from moderate to high. This allows to avoid the initial isolation of their antimony-capped precursors and, therefore, the use of the toxic trialkylantimony derivatives.

Acknowledgements. The synthesis of the hybrid complexes was supported by the Russian Science Foundation (project 16-13-10475). Their spectral characterization was performed with the financial support from the Russian Foundation for Basic Research (projects 16-03-00368 and 17-03-00587).
Table 1. The isolated yields of the metallophthalocyaninato-capped tris-pyridineoximates, which were obtained using a direct selfassembly and by a transmetallation reaction.

\begin{tabular}{ccc}
\hline & \multicolumn{2}{c}{ Yield, \% } \\
\cline { 2 - 3 } & $\begin{array}{c}\text { One-pot } \\
\text { reaction }\end{array}$ & $\begin{array}{c}\text { Trans- } \\
\text { metallation }^{[6]}\end{array}$ \\
\hline$\left[\mathrm{Fe}(\mathrm{AcPyOx})_{3}(\mathrm{ZrPc})\right]\left(\mathrm{ClO}_{4}\right)$ & 83 & 39 \\
{$\left[\mathrm{Fe}(\mathrm{AcPyOx})_{3}(\mathrm{HfPc})\right]\left(\mathrm{ClO}_{4}\right)$} & 72 & 42 \\
{$\left[\mathrm{Ni}(\mathrm{AcPyOx})_{3}(\mathrm{ZrPc})\right]\left(\mathrm{ClO}_{4}\right)$} & 68 & 50 \\
{$\left[\mathrm{Ni}(\mathrm{AcPyOx})_{3}(\mathrm{HfPc})\right]\left(\mathrm{ClO}_{4}\right)$} & 65 & 46 \\
\hline
\end{tabular}

\section{References}

1. Voloshin Y.Z., Kostromina N.A., Krämer R. Clathrochelates: Synthesis, Structure and Properties. Amsterdam: Elsevier, 2002. $432 \mathrm{p}$.

2. Voloshin Y.Z., Belaya I.G., Krämer R. Cage Metal Complexes: Clathrochelates Revisited. Springer International Publishing, 2017. 467 p.

3. Voloshin Y.Z., Varzatskii O.A., Korobko S.V., Chernii V.Y., Volkov S.V., Tomachynski L.A., Pehn'o V.I., Antipin M.Yu., Starikova Z.A. Inorg. Chem. 2005, 44, 822-824.

4. Voloshin Y.Z., Varzatskii O.A., Tomilova L.G., Breusova M.O., Magdesieva T.V., Bubnov Yu.N., Krämer R. Polyhedron 2007, 26, 2733-2740.

5. Dudkin S.V., Erickson N.R., Vologzhanina A.V., Novikov V.V., Rhoda H.M., Holstrom C.D., Zatsikha Yu.V., Yusubov M.S., Voloshin Y.Z., Nemykin V.N. Inorg. Chem. 2016, 55, 11867-11882.

6. Dudkin S.V., Belov A.S., Nelyubina Yu.V., Savchuk A.V., Pavlov A.A., Novikov V.V., Voloshin Y.Z. New. J. Chem. 2017, 41, 3251-3259.

7. Zelinskii G.E., Dudkin S.V., Chuprin A.S., Pavlov A.A., Vologzhanina A.V., Lebed G.E., Zubavichus Y.V., Voloshin Y.Z. Inorg. Chim. Acta. 2017, 463, 29-35. 